Syntax Literate: Jurnal Ilmiah Indonesia p-ISSN: 2541-0849

e-ISSN: 2548-1398

Vol. 5, No. 7, Juli 2020

\title{
PENGARUH HARGA DAN PROMOSI TERHADAP KEPUTUSAN PEMBELIAN SIM CARD AXIS
}

\section{Nasir Asman dan Nina Apriliani}

Fakultas Keguruan dan Ilmu Pendidikan Universitas Swadaya Gunung Jati Cirebon

Email: nasirasman85@gmail.com dan nina.apriliani123@gmail.com

\begin{abstract}
Price is one of the important factors in terms of service providers to win a competition in marketing their products. While promotion is a communication activity that aims to inform and influence consumers to be interested in buying products or services that are marketed. The formulation of the problem of this research is how the partial effect of the price and promotion on the purchase decision of the AXIS sim card, and how the price and promotion influence simultaneously to the purchase decision of the AXIS sim card.This study aims to determine the effect of price and promotion on the purchase decision of the AXIS Sim card. The population is used in this study were students in FKIP campus 2 Swadaya Gunung Jati Cirebon University with a total of 1339, a sample of 93 respondents using Incidental Sampling techniques. The method used in this study is quantitative with a survey approach. The results of the study show that prices and promotions have a good influence on the purchase decision of the AXIS sim card. Simultaneous testing results show that price and promotion variables together have a positive and significant influence on purchasing decisions. This can be proven by the simultaneous value of the determination coefficient of $60.9 \%$.
\end{abstract}

Keywords: Price; Promotion; Purchase Decision

Abstrak

Harga merupakan salah satu faktor penting dari sisi penyedia jasa untuk memenangkan suatu persaingan dalam memasarkan produknya. Sedangkan promosi adalah salah satu aktivitas komunikasi yang bertujuan untuk menginformasikan dan memberi pengaruh kepada konsumen agar tertarik membeli produk atau jasa yang dipasarkannya. Rumusan masalah penelitian ini adalah bagaimana pengaruh harga dan promosi secara parsial terhadap keputusan pembelian sim card AXIS, serta bagaimana pengaruh harga dan promosi secara simultan terhadap keputusan pembelian sim card AXIS. Penelitian ini bertujuan untuk mengetahui pengaruh harga dan promosi secara parsial maupun secara bersama-sama terhadap keputusan pembelian sim card AXIS. Populasi yang digunakan dalam penelitian ini adalah mahasiswa yang ada di FKIP kampus 2 Universitas Swadaya Gunung Jati Cirebon dengan jumlah 1339, sampel sebesar 93 responden dengan menggunakan teknik sampling insidental. Metode yang digunakan dalam penelitian ini adalah kuantitatif dengan pendekatan survei. Hasil penelitian menunjukan bahwa harga dan promosi berpengaruh cukup baik terhadap keputusan pembelian sim card AXIS. Hasil pengujian secara simultan menunjukan 
bahwa variabel harga dan promosi secara bersama-sama memiliki pengaruh yang positif dan signifikan terhadap keputusan pembelian. Hal ini dapat dibuktikan dengan nilai perolehan uji koefisien determinasi secara simultan sebesar 60,9\%.

Kata kunci : Harga; Promosi; Keputusan Pembelian.

\section{Pendahuluan}

Peningkatan taraf hidup masyarakat berpengaruh terhadap perubahan kebutuhan masyarakat akan sarana komunikasi. Pada awalnya surat menjadi alternatif dalam komunikasi kemudian berkembangan dengan telepon rumah dan di susul dengan munculnya telpon genggam (handphone) yang merupakan dampak penyesuaian terhadap mobilitas masyarakat yang semakin maju. Handphone kini mampu menemani masyarakat dalam berbagai aktivitas dengan tingginya mobilitas masyarakat, mampu mengupdate berita terkini dan mampu memiliki fitur pelayanan yang lengkap. Perkembangan dan kemajuan teknologi informasi sangat berpengaruh terhadap perubahan perilaku dan lingkungan maupun masyarakat secara umum. Perubahanperubahan yang terjadi mengarah pada efektifitas dan efisiensi kerja, ini terjadi karena dampak adanya internet.

Dewasa ini teknologi komunikasi tidak hanya menjadi kebutuhan masyarakat umum melainkan sudah berkembang menjadi lading bisnis yang prospektif. Bisnis operator saluler dari tahun ke tahun terus meningkat seiring perkembangan zaman. Selain itu didukung pula dengan hadirnya telepon saluler murah yang mampu dijangkau bebagai lapisan masyarakat hingga bisnis operator saluler pun semakin menjamur di Indonesia. Pergerakan pasar telepon saluler kini sudah merambah kalangan masyarakat bawah, pasar bisnis saluler di Indonesia tampaknya memang tergolong menggiurkan. Tidak heran jika para pelaku usaha bisnis saluler begitu agresif dalam bersaing memperebutkan pasar. Awal dari kelahiran industri saluler di Indonesia didominsai oleh dua operator saluler besar yang berbasis GSM (Global system for Mobile Communication), yaitu PT. Indosat Tbk dan PT. Telekomunikasi Saluler (Telkomsel). Beberapa tahun kemudian hadirlah operator saluler dengan nama PT. Exelcomindo Pratama. Kemudian disusul dengan munculnya berbagai operator, seperti Three (3) yang merupakan produk keluaran Hutchison Charoenn Pokphand Telekom, kemudian disusul PT. AXIS Telekom Indonesia dengan merk dagang AXIS. Para perusahaan tersebut berlomba-lomba melakukan berbagai macam cara agar dapat memenuhi permintaan konsumen terhadap kebutuhan komunikasi yang terus meningkat. Diantara begitu banyaknya perusahaan operator saluler, salah satunya adalah AXIS.

PT. AXIS Telekom Indonesia (sebelumnya bernama PT. Natrindo Telepon Saluler) dengan merek dagang AXIS, meluncurkan layanan pada April 2008 dan tahun 2012 tersedia dari 400 kota diseluruh pulau-pulau besar di Indonesia, termasuk Jawa, Sumatera, Kalimantan, Sulawesi, Bali, dan Lombok. Berkantor pusat di Jakarta, AXIS merupakan operator saluler $2 \mathrm{G}, 3 \mathrm{G}$, dan $4 \mathrm{G}$ dengan pertumbuhan tercepat di Indonesia, melayani lebih dari 15 juta pelanggan telepon saluler. Pada 30 Maret 2015, AXIS 
kembali hadir dengan wajah baru setelah bergabung dengan PT. XL Axiata. Kini merek layanan yang identik dengan warna ungu itu menawarkan gaya hidup baru dalam menggunakan layanan telekomunikasi melalui penyedia layanan yang simpel, terutama untuk sekedar menelepon, SMS, dan data/internet sesuai kebutuhan dengan tarif irit. Pengenalan kembali AXIS kali ini ditandai dengan peluncuran program gaya hidup "iritology" yakni pelayanan ngobrol irit, ngenet irit, awet irit, dan AXIS Hura-Hura. Paket internet AXIS merupakan salah satu paket internet yang paling di cari oleh anak muda dan anak sekolahan karena harganya yang bersahabat dan bonus-bonusnya sangat menarik. Pada tahun 2018 ini, AXIS menawarkan beberapa paket atau promo untuk pelanggan setianya diantaranya yaitu promo rabu rawit, jum'at baik, paket bronet 4G owsem, paket kangen nelpon ke operator lain, paket internet irit (2G/3G/4G), paket KZL, dan pekat irit nelpon dan sms.

\section{Tabel 1}

Top Brand Index SIM Card Prabayar

\begin{tabular}{ccc}
\hline Merek & $\begin{array}{c}\text { Top Brand Index } \\
\mathbf{2 0 1 6}\end{array}$ & $\begin{array}{c}\text { Top Brand Index } \\
\mathbf{2 0 1 7}\end{array}$ \\
\hline Simpati & $35.5 \%$ & $34.6 \%$ \\
\hline IM3 & $15.4 \%$ & $13.6 \%$ \\
\hline XL Prabayar & $14.8 \%$ & $13.4 \%$ \\
\hline Tri 3 & $11.3 \%$ & $11.4 \%$ \\
\hline Kartu AS & $10.4 \%$ & $8.6 \%$ \\
\hline axis & $5.1 \%$ & $5.6 \%$ \\
\hline
\end{tabular}

Sumber :www.topbrand-award.com

Berdasarkan tabel di atas bahwa sim card AXIS mengalami kenaikan dari tahun 2016 ke tahun 2017. Pada tahun 2016 presentasi peminat sim card AXIS sebesar 5.1\% mengalami kenaikan sebesar 5.6\%. Dari kenaikan tersebut dapat diduga ada faktor yang mempengaruhinya.

Harga merupakan salah satu faktor penting dari sisi penyedia jasa untuk memenangkan suatu persaingan dalam memasarkan produknya. Harga adalah nilai tukar yang harus dikeluarkan oleh seseorang untuk memperoleh suatu produk atau pelayanan jasa yang diinginkan. Menurut Deliyanti 2012 dalam (Sudaryono, 2018), "Harga (price) adalah suatu nilai tukar yang bisa disamakan dengan uang atau barang lain untuk manfaat yang diperoleh dari suatu barang atau jasa bagi seseorang atau kelompok pada waktu tertentu dan tempat tertentu."

AXIS merupakan salah satu operator yang banyak digunakan oleh kalangan pelajar, seperti siswa SMP, SMA, dan Mahasiswa. Di zaman modern seperti ini, telepon saluler merupakan salah satu kebutuhan yang sangat penting, disamping untuk berkomunikasi telepon saluler digunakan untuk mencari berbagai informasi yang dibutuhkan para pelajar. Apalagi dikalangan mahasiswa internet tidak lepas dari berbagai kegiatan dalam perkuliahan. Untuk itu, mahasiswa membutuhkan operator saluler yang sesuai dengan kondisi keuangan para mahasiswa dengan harga yang terjangkau. Sehingga harga mempengaruhi suatu keputusan pembelian konsumen. 
Menurut Schiffman dan Kanuk dialihbahasakan (Sumarwan, 2011) mendefinisikan bahwa, "Keputusan pembelian adalah suatu keputusan sebagai pemilihan suatu tindakan dari dua atau lebih pilihan alternatif."

Pengertian di atas dapat dianalisis bahwa pengambilan keputusan konsumen adalah suatu proses memilih salah satu dari beberapa alternatif pilihan yang ada dengan pengenalan maupun penyelesaian masalah yang dikumpulkan oleh seorang konsumen dan mewujudkannya dengan tindakan yang nyata. Setelah proses tersebut, barulah konsumen dapat mengevaluasi pilihannya, dan menentukan akan sikap yang diambil selanjutnya untuk menggunakan produk atau jasa tersebut.

AXIS dalam mempromosikan produknya cukup menarik, dimedia televisi banyak terdapat iklan AXIS yang dalam penyajiannya sangat menarik dan unik. Sehingga hal tersebut mempengaruhi suatu konsumen dalam mengambil keputusan untuk menggunakan sim card AXIS.

Promosi merupakan salah satu bagian dari rangkaian pemasaran untuk menginformasikan suatu produk atau jasa. Promosi adalah salah satu aktivitas komunikasi yang bertujuan untuk menginformasikan dan memberi pengaruh kepada konsumen agar tertarik membeli produk atau jasa yang dipasarkannya. Menurut (Wijayanti, 2017), "promosi merupakan salah satu kegiatan bauran marketing (pemasaran) yang sangat penting dalam keberhasilan suatu produk atau barang atau jasa atau bisnis apapun".Semakin baik perusahaan dalam melakukan kegiatan bauran pemasaran salah satunya yaitu meningkatkan kualitas produk dan menjaga eksistensi produk dengan cara melakukan kegiatan promosi yang tepat sasaran, maka konsumen akan mudah mendapatkan informasi produk yang ditawarkan perusahaan. pelayanan terbaik pada pelanggan (excellent) dan tingkat kualitas pelayanan merupakan cara terbaik yang eksternal dan biaya) dan sistem kinerja cara pelayanan standar pelayanan internal, biaya dan keuntungan konsisten untuk dapat mempertemukan harapan konsumen (standar pelayanan eksternal dan biaya) dan sistem kinerja cara pelayanan standar pelayanan internal biaya dan keuntungan (Yamit, 2010). Dengan demikian, tujuan perusahaan dalam memperoleh laba/ keuntungan akan tercapai melalui adanya Keputusan Pembelian. Menurut (Nugroho, 2017) proses pengambilan keputusan terbatas terjadi apabila konsumen atau pengambil keputusan terlebih dulu mengenali masalah produk.

Berdasarkan uraian di atas maka peneliti tertarik untuk melakukan penelitian dengan judul "Pengaruh Harga dan Promosi Terhadap Keputusan Pembelian Sim Card AXIS (Survei Pada Mahasiswa FKIP Kampus 2 Universitas Swadaya Gunung Jati Cirebon)"

\section{Metode Penelitian}

Jenis penelitian yang digunakan adalah deskriptif kuantitatif karena adanya hipotesis yang akan di uji menggunakan alat uji statistik. Pendekatan kuantitatif dilakukan untuk mengkuantifikasi data dan membuat generalisasi terhadap populasi 
berdasarkan hasil yang diperoleh dari penelitian terhadap sampel. Dalam penelitian ini data dikumpulkan secara terstruktur dan dianalisis dengan menggunakan statistik.

Metode yang digunakan dalam penelitian ini, penulis menggunakan metode penelitian survei. Menurut (Sugiyono, 2017) mengungkapkan bahwa secara umum metode survei, yaitu: "Metode survei digunakan untuk mendapatkan data dari tempat tertentu yang alamiah (bukan buatan), tetapi penelitian melakukan perlakuan dalam pengumpulan data, misalnya dengan mengedarkan kuesioner, tes, wawanacara terstruktur dan sebagainya (perlauan tidak seperti dalam eksperimen)."

Menurut Van Dalen dalam (Arikunto, 2014) "Survei merupakan bagian dari studi deskriptif yang bertujuan untuk mencari kedudukan (status) fenomena (gejala) dan menentukan status dengan cara membandingkan standar yang sudah ditentukan." "penelitian survei adalah penelitian yang mengambil sampel dari satu populasi dan menggunakan kuesioner sebagai alat pengumpulan data yang pokok". Penelitian survei ini dilakukan pada pelanggan produk cake Cirebon Kelana yang beralamat di Jalan Siliwangi No. 169 Kejaksan Kota Cirebon, Jawa Barat 45123 (Tukiran, 2012).

Berdasarkan pemaparan tersebut, dapat dianalisis bahwa penelitian survei adalah metode pengumpulan data dari responden yang dapat diperoleh melalui berbagai pertanyaan atau pernyataan dalam bentuk tes, kuesioner, maupun wawancara tersetruktur yang dapat dilontarkan oleh peneliti dengan tujuan untuk mencari kedudukan atau fenomena alamiah yang terjadi.

Populasi pada penelitian ini adalah Mahasiswa FKIP Kampus 2 Unswagati Cirebon, Pengambilan sampel yang digunakan pada penelitian ini adalah teknik pengambilan sampel secara sampling insidental "Sampling Insidental adalah teknik pengambilan sampel berdasarkan insidental (kebetulan) ditemui dan sesuai dengan karakteristik tertentu sesuai dengan sumber data" (Sugiyono, 2017). Adapun sampel yang diambil dari prodi Ekonomi sebanyak 28 mahasiswa, prodi Matematika sebanyak 29 mahasiswa, dan prodi Bahasa Indonesia sebanyak 36 mahasiswa. Teknik pengumpulan data dalam penelitian ini adalah sebagai berikut:

\section{Kuesioner (angket)}

Merupakan teknik pengumpulan data yang dilakukan dengan cara memberi seperangkat pertanyaan atau pernyataan tertulis pada responden untuk dijawabnya (Sugiyono, 2018).

\section{Studi Kepustakaan}

Studi kepustakaan merupakan pengumpulan data dengan cara menelususri sumber-sumber tulisan yang pernah dibuat sebelumnya. Tulisan tersebut berkaitan dengan topik yang diangkat dalam penelitian ini. Studi kepustakaan bisa didapatkan dari jurnal, buku, internet dan lain sebagainya.

\section{Studi Dokumentasi}

Riduwan mengatakan bahwa "studi dokumentasi dilakukan untuk memperoleh data langsung dari tempat penelitian, meliputi buku-buku yang relevan, peraturan-peraturan, laporan kegiatan, foto-foto, film dokumenter, data yang relevan penelitian" (Riduwan, 2015). Perlunya studi dokumentasi adalah 
untuk menguatkan hasil penelitian serta mengabadikan secara langsung kegiatan penelitian.

\section{Hasil dan Pembahasan}

\section{A. Hasil Penelitian}

\section{Analisis Data}

\section{a. Uji Asumsi Klasik}

Uji asumsi klasik adalah analisis yang dilakukan untuk menilai apakah di dalam sebuah model regresi linier Ordinary Least Square (OLS) terdapat masalah-masalah asumsi klasik. Uji asumsi klasik bertujuan untuk menghasilkan nilai parameter yang baik sehingga hasil penelitian dapat lebih diandalkan.

\section{1) Uji Normalitas}

Uji normalitas data digunakan sebagai prasyarat untuk melakukan uji regresi. Uji normalitas bertujuan untuk mengetahui distribusi data dalam variabel yang akan digunakan dalam penelitian, apakah data yang di ambil dari populasi berdistribusi normal atau tidak. Normalitas data dapat dilihat dengan menggunakan uji Kolmogorov-Smirnov (Sujarweni, 2015). Perhitungan uji normalitas dilakuakan dengan bantuan program SPSS versi 24.

\section{Tabel 2}

Hasil Uji Normalitas

\begin{tabular}{|c|c|c|c|c|}
\hline \multicolumn{5}{|c|}{ One-Sample Kolmogorov-Smirnov Test } \\
\hline & & Harga (X1) & Promosi (X2) & $\begin{array}{c}\text { Keputusan } \\
\text { Pembelian }(\mathrm{Y})\end{array}$ \\
\hline $\mathrm{N}$ & & 93 & 93 & 93 \\
\hline \multirow[t]{2}{*}{ Normal Parameters ${ }^{\mathrm{a}, \mathrm{b}}$} & Mean & 59.62 & 59.41 & 59.20 \\
\hline & Std. Deviation & 2.553 & 2.687 & 3.067 \\
\hline \multirow[t]{3}{*}{ Most Extreme Differences } & Absolute & .102 & .095 & .097 \\
\hline & Positive & .091 & .077 & .075 \\
\hline & Negative & -.102 & -.095 & -.097 \\
\hline Test Statistic & & .102 & .095 & .097 \\
\hline Asymp. Sig. (2-tailed) & & $.057^{\mathrm{c}}$ & $.076^{\mathrm{c}}$ & $.081^{\mathrm{c}}$ \\
\hline \multicolumn{5}{|l|}{ a. Test distribution is Normal. } \\
\hline b. Calculated from data. & & & & \\
\hline
\end{tabular}

(Sumber: Pengolahan data penulis menggunakan program SPSS 24)

Kriteria Pengambilan Keputusan:

Jika nilai Signifikansi /P-value/ Sig. $<0,05$ artinya data tidak normal

Jika nilai Signifikansi /P-value/ Sig. > 0,05 artinya data normal 
Berdasarkan tabel di atas pada data harga, promosi, dan keputusan pembelian SIM Card dengan tingkat kepercayaan $\alpha=0,05$ diperoleh nilai signifikansi (Sig.) uji Kolmogorov-Smirnov (0,057, 0,076 dan 0,0.81) kesemuanya $>0,05$, artinya data berdistribusi secara normal.

\section{2) Uji Multikolineritas}

Menurut (Imam, 2011) "model regresi yang baik seharusnya tidak terjadi korelasi diantara variabel independen. Jika diantara variabel saling berkorelasi, maka variabel-variabel ini tidak orthogonal". Uji multikolineritas diperlukan untuk mengetahui ada tidaknya variabel yang memiliki kemiripan antar variabel independen dalam suatu model. Kemiripan antar variabel independen akan mengakibatkan korelasi sangat kuat. Menurut (Umar, 2014) "uji multikolinearitas digunakan untuk mengetahui apakah pada model regresi ditemukan adanya antar variabel independen, jika terjadi korelasi, terdapat masalah multikolinearitas yang harus diatasi”. Selain itu uji ini juga untuk menghindari kebiasaan dalam pengambilan keputusan mengenai pengaruh pada uji parsial maing-maing variabel independen terhadap variabel dependen. Jika VIF (Variance Inflation Factor) yang dihasilkan diantara 1-10 maka tidak terjadi multikolineritas (Sujarweni, 2015). Perhitungan Multikolinieritas dilakukan dengan program SPSS versi 24.

Tabel 3 Uji Multikolinieritas

\begin{tabular}{llll}
\hline \multirow{2}{*}{ Model } & & \multicolumn{2}{c}{ Collinearity Statistics } \\
\cline { 2 - 4 } Tolerance & VIF \\
\hline 1 & & & \\
\cline { 2 - 4 } & (Constant) & .744 & 1.344 \\
\cline { 2 - 4 } & Harga (X1) & .744 & 1.344 \\
\hline
\end{tabular}

(Sumber: Pengolahan data penulis menggunakan program SPSS 24

Apabila nilai tolerance value lebih tinggi dari pada 0,10 atau VIF lebih kecil daripada 10 maka dapat disimpulkan tidak terjadi multikolinearitas. Karena data di atas semuanya $>0,10 \& \mathrm{VIF}<10$, maka dapat disimpulkan bahwa tidak terjadi multikolinieriti.

\section{3) Uji Autokorelasi}

Uji autokorelasi adalah Sebuah analisis statistik yang dilakukan untuk mengetahui adakah korelasi variabel yang ada di dalam model prediksi dengan perubahan waktu.

Ketentuan pengambilan keputusan:

Jika $0<\mathrm{DW}<\mathrm{dL}$, maka terjadi autokorelasi

Jika $\mathrm{dL} \leq \mathrm{DW} \leq \mathrm{dU}$, tidak dapat diketahui terjadi autokorelasi atau tidak

Jika $4-\mathrm{dL}<\mathrm{DW}<4$, maka terjadi autokorelasi

Jika $4-\mathrm{dU} \leq \mathrm{DW} \leq 4-\mathrm{dL}$, tidak dapat diketahui terjadi autokorelasi atau tidak 
Jika dU $<$ DW $<4-$ dU, maka tidak terjadi autokorelasi.

\section{Tabel 4}

Uji Autokorelasi

\begin{tabular}{lll}
\hline Model & Durbin-Watson \\
\hline 1 & 1.061 \\
\hline
\end{tabular}

(Sumber: Pengolahan data penulis menggunakan program SPSS 24)

Nilai Durbin-Watson $=1,061$ berada pada rentang $0-3$, karena berada pada rentang tersebut maka disimpulkan tidak terjadi autokorelasi.

\section{4) Uji Heteroskedastisitas}

Uji Heteroskedastisitas digunakan untuk menguji apakah dalam model regresi terjadi ketidaksamaan variance dari residu satu pengamatan ke pengamatan yang lain. Kemungkinan adanya gejala heteroskedastisitas dapat dilakukan dengan menggunakan diagram scatterpoot, dimana sumbu $\mathrm{X}$ adalah residul dan sumbu $\mathrm{Y}$ adalah nilai $\mathrm{Y}$ yang diprediksi. Jika pada grafik tidak ada pola yang jelas serta titik-titik menyebar di atas dan di bawah sumbu 0 (nol) pada sumbu Y, maka tidak terjadi heteroskedastisitas dalam satu model regresi.

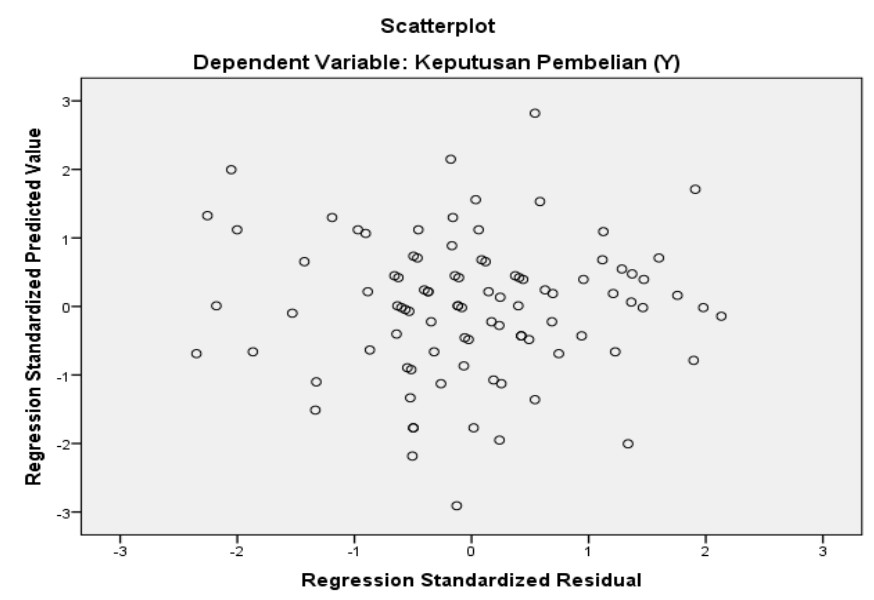

Gambar 1

\section{Uji Heteroskedastisitas}

(Sumber: Pengolahan data penulis menggunakan program SPSS 24)

Grafik Scatter, jelas bahwa tidak ada pola tertentu karena titik meyebar tidak beraturan di atas dan di bawah sumbu sumbu Y. Maka dapat disimpulkan tidak terdapat gejala heteroskedastisitas.

\section{Pengujian Hipotesis}

Pengujian hipotesis adalah prosedur yang mendasar pada bukti sampel yang dipakai untuk menentukan wajar tidaknya pernyataan oleh karenanya tidak ditolak, atau hipotesis itu tidak wajar dan oleh karena itu harus ditolak. 
Pengujian hipotesis dalam penelitian ini bertujuan untuk mengetahui apakah harga dan promosi berpengaruh terhadap keputuan pembelian sim card AXIS di Lingkungan Mahasiswa FKIP Kampus 2 Universitas Swadaya Gunung Jati Cirebon.

\section{a. Uji Regresi Ganda}

Uji regresi ganda digunakan untuk mengetahui pengaruh antara variabel bebas terhadap variabel terikat. Metode analisis ini digunakan dengan tujuan untuk mengetahui ada tidaknya pengaruh variabel harga $\left(X_{1}\right)$ dan promosi $\left(X_{2}\right)$ terhadap keputusan pembelian $(Y)$. Berikut ini adalah hasil uji regresi ganda menggunakan SPPS Versi 24:

\section{Tabel 5}

Hasil Output Regresi Ganda

\begin{tabular}{|c|c|c|c|c|c|}
\hline \multicolumn{6}{|c|}{ Coefficients $^{\mathrm{a}}$} \\
\hline \multirow[b]{2}{*}{ Model } & \multicolumn{2}{|c|}{$\begin{array}{c}\text { Unstandardized } \\
\text { Coefficients }\end{array}$} & \multirow{2}{*}{$\begin{array}{c}\begin{array}{c}\text { Standardized } \\
\text { Coefficients }\end{array} \\
\text { Beta }\end{array}$} & \multirow[b]{2}{*}{$\mathrm{T}$} & \multirow[b]{2}{*}{ Sig. } \\
\hline & $\mathrm{B}$ & Std. Error & & & \\
\hline (Constant) & -3.236 & 5.306 & & .610 & -.544 \\
\hline Harga $(\mathrm{X} 1)$ & .492 & .092 & .410 & 5.364 & .000 \\
\hline $\begin{array}{l}\text { Promosi } \\
\text { (X2) }\end{array}$ & .557 & .087 & .488 & 6.385 & .000 \\
\hline a. Dependen & Kep & san Pemb & $n(Y)$ & & \\
\hline
\end{tabular}

(Sumber: pengolahan data penulis menggunakan SPSS 24)

Pada tabel di atas menunjukkan regresi yang dicari. Nilai sig untuk variabel harga $\left(\mathrm{X}_{1}\right)$, promosi $\left(\mathrm{X}_{2}\right)$, adalah $(0,000,0,000<0,05)$ dengan demikian dapat disimpulkan bahwa nilai pada kolom B adalah signifikan artinya persamaan yang paling tepat untuk variabel tersebut adalah:

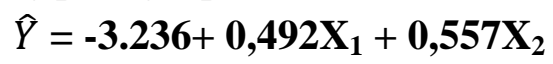

Keputusan pembelian $=\mathbf{- 3 . 2 3 6}+\mathbf{0 , 4 9 2} \mathbf{X}_{\mathbf{1}}($ harga $)+\mathbf{0 , 5 5 7} \mathbf{X}_{2}($ promosi $)$

1. Nilai konstanta -3.236 , hal ini menyatakan bahwa jika tidak ada kenaikan nilai dari variabel harga $\left(\mathrm{X}_{1}\right)$, dan promosi $\left(\mathrm{X}_{2}\right)$, maka nilai keputusan pembelian (Y) adalah -3.236 atau -3.236 poin.

2. Koefisien regresi, Koefisien regresi $X_{1}$ sebesar 0,492. Hal ini menyatakan bahwa setiap terjadi penambahan satu skor atau nilai harga akan menaikan keputusan pembelian sebesar 0,492 atau 4,92 poin.

3. Sedangkan koefisien pada variabel $\mathrm{X}_{2}$ sebesar 0,557. Hal ini menyatakan bahwa setiap terjadi penambahan satu skor atau promosi akan meningkatkan keputusan pembelian sebesar 0,557 atau 5,57 poin.

Selanjutnya dilakukan uji t, hal ini dimaksudkan untuk menguji signifikansi konstanta dan variabel dependen. Kriteria uji koefisien regresi dari variabel harga $\left(\mathrm{X}_{1}\right)$ dan promosi $\left(\mathrm{X}_{2}\right)$ terhadap keputusan pembelian $(\mathrm{Y})$ sebagai berikut: 
Ho = harga dan promosi tidak berpengaruh signifikan terhadap keputusan pembelian.

$\mathrm{Ha}=$ harga dan promosi berpengaruh signifikan terhadap keputusan pembelian.

Dengan kriteria pengambilan keputusan sebagai berikut:

Jika nilai $t_{\text {hitung }} \geq t_{\text {tabel}}$, maka Ho ditolak artinya koefisien regresi signifikan

Jika nilai $t_{\text {hitung }} \leq \mathrm{t}_{\text {tabel }}$, maka Ho diterima artinya koefisien regresi tidak signifikan.

Berdasarkan koefisien regresi $\mathrm{X}_{1}$, dan $\mathrm{X}_{2}$ diperoleh nilai $\mathrm{t}_{\text {hitung }}$ sebesar 5,364 dan 6,385. Dengan tingkat signifikansi $\alpha=0,05$ dan $\mathrm{dk}(\mathrm{n}-2)=93-2=$ 91 dilakukan uji satu pihak, sehingga diperoleh nilai $t_{\text {tabel }}$ adalah 1,986. Karena nilai $t_{\text {hitung }} \geq t_{\text {tabel }}$ atau $(5,364$ dan $6,385 \geq 1,986)$ maka Ha diterima dan Ho ditolak, artinya koefisien regresi signifikan atau dengan kata lain harga dan promosi berpengaruh signifikan terhadap keputusan pembelian.

Tabel 6

Uji Signifikansi dengan Perbandingan Nilai $t_{\text {hitung }}$ dan $t_{\text {tabel }}$

\begin{tabular}{llll}
\hline \multicolumn{1}{c}{ Variabel } & $\mathbf{t}_{\text {hitung }}$ & $\mathbf{t}_{\text {tabel }}$ & Ket \\
\hline Harga & 5,364 & 1,986 & Signifikan \\
\hline Promosi & 6,385 & 1,986 & Signifikan \\
\hline
\end{tabular}

(Sumber: pengolahan data penulis menggunakan SPSS 24)

\section{b. Uji Simultan (Uji F)}

Fungsi uji $\mathrm{F}$ yaitu untuk mengetahui apakah semua variabel antara variabel independen dan dependen saling berkaitan sehingga secara bersama-sama berpengaruh positif dan signifikan. Uji simultan (uji f) disini dilakukan untuk mengetahui variabel harga $\left(X_{1}\right)$ dan promosi $\left(X_{2}\right)$ secara bersama-sama berpengaruh terhadap keputusan pembelian $(Y)$ atau tidak. Berikut ini adalah hasil uji F menggunakan SPPS Versi 24:

Tabel 7

Hasil Output Uji F

\begin{tabular}{lcrrrr}
\hline \multicolumn{7}{c}{ ANOVA $^{\mathbf{a}}$} \\
\hline Model & Sum of Squares & Df & Mean Square & F & Sig. \\
\hline Regression & 526.568 & 2 & 263.284 & 69.991 & $.000^{\text {b }}$ \\
\hline Residual & 338.551 & 90 & 3.762 & & \\
\hline Total & 865.118 & 92 & & & \\
\hline
\end{tabular}

a. Dependent Variable: Keputusan Pembelian (Y)

b. Predictors: (Constant), Promosi (X2), Harga (X1)

(Sumber: pengolahan data penulis menggunakan SPSS 24)

\section{c. Hipotesis}

$\mathrm{H}_{0}$ : Tidak terdapat pengaruh harga (X1) dan promosi (X2) secara bersama-sama terhadap keputusan pembelian (Y) sim card AXIS

$\mathrm{H}_{\mathrm{a}}$ : Terdapat pengaruh harga (X1) dan promosi (X2) secara bersamasama terhadap keputusan pembelian (Y) sim card AXIS

Dengan kriteria pengambilan keputusan sebagai berikut: 
1) Jika $\mathrm{F}$ hitung $>\mathrm{F}$ tabel dengan $\mathrm{dk}$ pembilang $=\mathrm{k}$ dan $\mathrm{dk}$ penyebut $=\mathrm{n}-$ k-1 dan $\alpha=0,05$, maka Ho ditolak dan jika sebaliknya maka Ho diterima.

2) Jika sig < 0,05, maka Ho ditolak dan jika sebaliknya diterima.

Pada tabel ini terlihat bahwa $F_{\text {hitung }}$ sebesar 69,991 dan $F_{\text {tabel }}$ sebesar 3,097. Nilai $\mathrm{F}_{\text {tabel }}$ didapatkan menggunakan rumus $\mathrm{dk}=\mathrm{n}-2-1=93-2-1=90$, jadi $\mathrm{F}_{\text {tabel }}=3,087$ dengan nilai probabilitasnya atau sig. $=0,000<0,05$. Jadi dalam penelitian ini dapat disimpulkan bahwa harga dan promosi secara bersama-sama berpengaruh posiitif dan signifikan terhadap keputusan pembelian.

\section{d. Uji Koefisien Determinasi}

Pengujian koefisien determinasi bertujuan untuk mengetahui seberapa besarkah pengaruh variabel variabel harga $\left(X_{1}\right)$ dan promosi $\left(X_{2}\right)$ terhadap keputusan pembelian (Y). Berikut ini adalah hasil uji $\mathrm{F}$ menggunakan SPPS Versi 24:

\section{Tabel 8}

Uji Koefisien Determinasi

\begin{tabular}{lrrrrr}
\hline \multicolumn{6}{c}{ Model Summary $^{\mathbf{b}}$} \\
\hline Model & $\mathrm{R}$ & R Square & Adjusted R Square & \multicolumn{1}{c}{ Estimate } & Durbin-Watson \\
\hline 1 & $.780^{\mathrm{a}}$ & .609 & .600 & 1.940 & 1.061 \\
\hline
\end{tabular}

a. Predictors: (Constant), Promosi (X2), Harga (X1)

b. Dependent Variable: Keputusan Pembelian (Y)

(Sumber: pengolahan data penulis menggunakan SPSS 24)

Pada tabel ini terdapat $R$ Square sebesar 0,609 dari koefisien korelasi $(0,780) R$-Square di sebut koefisien determinansi $\left(\mathrm{D}=\mathrm{r}^{2} \mathrm{x} 100 \%=0,780^{2} \mathrm{x}\right.$ $100 \%=60,9 \%$ ) dalam hal ini $60,9 \%$ keputusan pembelian dapat dipengaruhi oleh variabel harga dan promosi sedangkan sisanya $(39,1 \%)$ di jelaskan variabel lain selain variabel yang digunakan dalam penelitian dan penulis abaikan.

\section{B. Pembahasan}

Penelitian yang dilakukan penulis meneliti mengenai pengaruh harga dan promosi terhadap keputusan pembelian sim card AXIS di kalangan mahasiswa FKIP kampus 2 Universitas Swadaya Gunung Jati Cirebon. Hasil yang diperoleh dalam penelitian ini yaitu hasil data angket yang telah di sebar kepada responden. Hal ini dilakukan untuk mengukur seberapa besar pengaruh harga dan promosi terhadap keputusan pembelian sim card AXIS di lingkungan mahasiswa FKIP kampus 2 Universitas Swadaya Gunung Jati Cirebon. Data yang sudah diperoleh 
tersebut diolah dan dianalisis menggunakan program program Microsoft Excel dan program SPSS versi 23. Adapun pembahasan penelitian ini mengacu kepada rumusan masalah yang telah tertulis pada bab sebelumnya dapat dilihat sebagai berikut:

\section{Bagaimana Pengaruh Harga Terhadap Keputusan Pembelian Sim Card AXIS}

Harga merupakan salah satu komponen penting yang digunakan untuk memutuskan suatu pilihan yang dilakukan oleh konsumen, konsumen akan membandingkan harga dari produk pilihan mereka dan kemudian mengevaluasi apakah harga tersebut sesuai atau tidak dengan nilai produk serta jumlah uang yang harus dikeluarkan. Harga yang ditawarkan oleh sim card AXIS terbilang cukup murah dan terjangkau hal ini dapat dilihat dari hasil data angket yang menunjukan bahwa mahasiswa banyak yang menjawab setuju.

Berdasarkan hasil perolehan data angket, hasil penelitian menunjukan bahwa secara umum harga berpengaruh terhadap keputusan pembelian sim card AXIS yang dilakukan di lingkungan mahasiswa FKIP kampus 2 Universitas Swadaya Gunung Jati Cirebon. Dilihat dari hasil rekapitulasi angket menunjukan bahwa harga memberi kontribusi sebesar $79,50 \%$ yang artinya harga mempunyai pengaruh yang cukup baik terhadap keputusan pembelian sim card AXIS.

Selain dari hasil rekapitulasi angket, penulis juga melakukan uji t dengan menggunakan SPSS v24 untuk menjawab apakah ada pengaruh antara variabel (X1) terhadap variabel (Y), berdasarkan hasil uji t yang telah dilakukan maka hasilnya adalah terdapat pengaruh antara variabel (X1) terhadap variabel $(\mathrm{Y})$. Hal ini terbukti dari nilai $t_{\text {hitung variabel }}(\mathrm{X} 1)$ yaitu harga adalah 5,364 artinya nilai tersebut lebih besar dari nilai $t_{\text {tabel }}$ yaitu $(5,364$ > 1,986). Maka dapat disimpulkan bahwa terdapat pengaruh yang signifikan antara variabel harga (X1) terhadap keputusan pembelian (Y). Adanya pengaruh yang signifikan ini mengindikasi bahwa terjangkaunya harga sebuah produk dapat meningkatkan keputusan pembelian konsumen. Karena di era modern seperti ini dimana teknologi begitu sangat dibutuhkan oleh konsumen dalam kegiatan sehari-hari, dengan begitu banyak operator saluler yang bermunculan dengan menawarkan berbagai harga yang terjangkau konsumen akan memilih dan memutuskan suatu produk atau jasa yang sesuai dengan kondisi keuangannya. Terutama dikalangan mahasiswa yang dalam pengambilan keputusannya untuk membeli barang atau jasa harus terjangkau dengan kondisi keuangan mereka.

Hasil ini sejalan dengan penelitian yang dilakukan oleh Agus Susanto pada tahun 2013 yang berjudul "Pengaruh Promosi, Harga dan Inovasi Produk Terhadap Keputusan Pembelian Pada Batik Tulis Karangmlati Demak" yang menyatakan bahwa harga berpengaruh positif dan signifikan terhadap keputusan pembelian. 


\section{Bagaimana Pengaruh Promosi Terhadap Keputusan Pembelian Sim Card AXIS}

Promosi merupakan salah satu kegiatan pemasaran yang dilakukan untuk mempengaruhi konsumen dalam memutuskan pembelian. Dengan adanya promosi yang dilakukan sim card AXIS dapat mempengaruhi konsumen untuk menggunakan produk atau jasanya. Suatu perusahaan akan melakukan berbagai hal untuk kegiatan memasarkan produk maupun jasanya agar dikenal oleh konsumen. Salah satunya dengan melakukan kegiatan promosi, perusahaan menginformasikan produk ataupun jasa kepada konsumen dalam bentuk promosi yang dilakukan melalui media cetak, massa maupun media elektronik yang dikemas secara menarik dan unik. Kegiatan promosi sendiri bisa dilakukan dengan mengadakan event-event tertentu maupun kegiatan pemasaran langsung kepada konsumen.

Berdasarkan hasil perolehan data angket, hasil penelitian menunjukan bahwa secara umum promosi berpengaruh terhadap keputusan pembelian sim card AXIS yang dilakukan di lingkungan mahasiswa FKIP kampus 2 Universitas Swadaya Gunung Jati Cirebon. Dilihat dari hasil rekapitulasi angket menunjukan bahwa promosi memberi kontribusi sebesar $79,21 \%$ yang artinya promosi mempunyai pengaruh yang cukup baik terhadap keputusan pembelian sim card AXIS.Adanya pengaruh yang cukup baik ini mengindikasi bahwa semakin baik dan semakin gencar suatu perusahaan melakukan promosi produk ataupun jasa yang ditawarkan maka akan mengakibatkan semakin baik pula suatu keputusan pembelian konsumen. Dengan promosi dan trobosantrobosan yang dilakukan perusahaan untuk mengenalkan produk ataupun jasa akan membuat konsumen tertarik untuk membeli.

Selain dari hasil rekapitulasi angket, penulis juga melakukan uji t dengan menggunakan SPSS v24 untuk menjawab apakah ada pengaruh antara variabel (X2) terhadap variabel (Y), berdasarkan hasil uji t yang telah dilakukan maka hasilnya adalah terdapat pengaruh antara variabel (X2) terhadap variabel (Y). Hal ini terbukti dari nilai $t_{\text {hitung variabel }}(\mathrm{X} 2)$ yaitu promosi adalah 6,385 artinya nilai tersebut lebih besar dari nilai $t_{\text {tabel }}$ yaitu $(6,385$ > 1,986). Maka dapat disimpulkan bahwa terdapat pengaruh yang signifikan antara variabel promosi (X2) terhadap keputusan pembelian (Y).

Hasil ini sejalan dengan penelitian yang dilakukan oleh (Setiawati, 2006) yang berjudul "Pengaruh Kualitas Produk dan Promosi Terhadap Keputusan Pembelian Kerupuk Rambak Dwijowo di Desa Penanggulan Kec. Pegandon Kab. Kendal" menyatakan bahwa variabel promosi secara parsial juga mempunyai pengaruh yang positif dan signifikan.

3. Bagaimana Pengaruh Harga Dan Promosi Secara Bersama-Sama Terhadap Keputusan Pembelian

Harga adalah suatu atribut produk atau jasa yang paling sering digunakan oleh sebagian besar konsumen untuk mengevaluasi produk. Untuk 
sebagian konsumen indonesia yang berpendapatan rendah maka harga merupakan faktor utama yang dipertimbangkan dalam memutuskan untuk memilih suatu produk maupun jasa. Selain harga salah satu bentuk persaingan dalam pelaku usaha adalah promosi. Suatu perusahaan dalam mempromosikan produknya harus dikemas secara menarik, dimedia televisi banyak terdapat iklan yang dalam penyajiannya sangat menarik dan unik. Hal ini dilakukan agar produk atau jasa yang ditawarkannya dikenal oleh konsumen. Ketika suatu produk maupun jasa sudah dikenal oleh konsumen maka otomatis konsumen akan merasa tertarik dan berminat untuk membeli produk atau jasa yang ditawarkan tersebut.

Berdasarkan hasil perolehan data angket, hasil penelitian menunjukan adanya pengaruh secara bersama-sama positif dan signifikan antara harga dan promosi terhadap keputusan pembelian sim card AXIS di lingkungan mahasiswa FKIP kampus 2 Universitas Swadaya Gunung Jati Cirebon. Di lihat dari hasil uji $\mathrm{F}$ untuk menjawab apakah ada pengaruh antara variabel (X1) dan (X2) secara bersama-sama terhadap variabel (Y), berdasarkan hasil uji f yang telah dilakukan maka hasilnya adalah terdapat pengaruh antara variabel (X1) dan (X2) terhadap variabel (Y). Hal ini terbukti dari nilai $F_{\text {hitung }}$ variabel (X1) harga dan (X2) promosi secara bersama-sama adalah 69,991 artinya nilai tersebut lebih besar dari nilai $F_{\text {tabel }}$ yaitu $(69,991>3,087)$ dengan nilai probabilitasnya atau sig $=0,000<0,05$. Maka dapat disimpulkan bahwa terdapat pengaruh yang signifikan antara variabel harga (X1) dan promosi (X2) secara bersama-sama terhadap keputusan pembelian (Y).

Hasil ini sejalan dengan penelitian yang dilakukan oleh (Mahardika, 2015) yang berjudul "Pengaruh Tarif dan Promosi Terhadap Keputusan Membeli Kartu Prabayar Produk Indosat IM3" menyatakan bahwa hasil nilai P Value sebesar 0,000 dimana lebih kecil dari signifikasi 0,05. Ini artinya variabel tarif dan promosi secara bersama-sama berpengaruh terhadap keputusan membeli kartu indosata IM3.

\section{Implikasi Penerapan Hasil Penelitian terhadap Dunia Pendidikan}

Penelitian ini membahas mengenai pengaruh harga dan promosi terhadap keputusan pembelian. suatu perusahaan dalam menjalankan bisnisnya tidak terlepas dari ilmu tentang strategi pemasaran untuk dapat mempengaruhi minat beli konsumen dalam memperkenalkan produk ataupun jasa. dalam hal ini ilmu dasar manajemen pemasaran sangatlah diperlukan yang nantinya akan dijadikan acuan dalam mejalankan bisnis suatu perusahaan. Maka jika dikaitkan dengan dunia pendidikan kita mengenal manajemen pemasaran, dimana dalam ruang lingkup manajemen pemasaran terdapat suatu pembahasan mengenai bauran pemasaran (Marketing Mix) adalah variabel-variabel yang disusun oleh perusahaan dalam rangka untuk memuaskan target market tersebut. Bauran pemasaran adalah kombinasi dari empat variabel atau kegiatan yang merupakan inti dari sistem pemasaran perusahaan, yaitu : produk, struktur 
harga, kegiatan promosi dan sistem saluran distribusi. Variabel-variabel marketing mix ini dapat dipakai sebagai dasar untuk mengambil suatu strategi dalam usaha mendapatkan posisi yang sangat strategis dipasar. Menurut (Assauri, 2015), “marketing mix merupakan kombinasi variabel atau kegiatan yang merupakan inti dari sistem pemasaran, variabel yang dapat dikendalikan oleh perusahaan untuk mempengaruhi reaksi para pembeli atau konsumen. Terdapat empat unsur atau variabel dalam bauran pemasaran yaitu produk, harga, penyaluran/distribusi dan promosi”.

Harga dan promosi merupakan variabel yang terdapat dalam kegiatan marketing mix yang berpengaruh terhadap suatu keputusan pembelian konsumen. Dalam dunia pendidikan pengaruh harga dan promosi terhadap keputusan pembelian berkaitan dengan pembelajaran manajemen pemasaran yang di dalamnya terdapat teori-teori tentang bauran pemasaran (Marketing Mix) yang nantinya diterapkan dalam dunia kerja mauapun dalam menjalankan wirausaha. Hal ini mempermudah pendidik untuk menginformasikan kepada peserta didiknya mengenai bagaimana tata cara menjalankan suatu perusahaan atau berwirausaha yang baik dan benar agar produknya bisa bersaing dipasar dan banyak diminati oleh konsumen. Hal ini dilakukan untuk memberikan gambaran kepada peserta didik yang kelak bekerja di perusahaan sebagai manajer marketing ataupun memiliki usaha sendiri, bahwa dalam menjalankan suatu usaha bukan hanya modal dan tenaga kerja sebagai faktor utama, tetapi harus bisa menentukan faktor pendukung lainnya yang pada saat menjalankan usahanya dapat memberikan dampak positif seperti tercapainya tujuan dan mendapatkan keuntungan seoptimal mungkin. Dalam hal ini faktor pendukung yang telah terbukti hasilnya sesuai dengan hasil penelitian yang telah dilakukan penulis adalah pengaruh harga dan promosi terhadap keputusan pembelian, dimana harga dan promosi dalam bauran pemasaran memiliki pengaruh terhadap keputusan pembelian konsumen yang menggunakan sim card AXIS.

\section{Kesimpulan}

Berdasarkan hasil dari beberapa pengujian yang dilakukan oleh penulis, yaitu pengujian statistik deskriptif, asumsi klasik, sampai dengan pengujian hipotesis, maka dapat disimpulkan bahwa harga dan promosi berpengaruh terhadap keputusan pembelian sim card AXIS di lingkungan mahasiswa FKIP kampus 2 Universitas Swadaya Gunung Jati Cirebon. Berikut simpulan mengenaai hasil pengujian yang telah dilakukan berdasarkan hipotesis yang telah dirumuskan:

Pertama, Berdasarkan hasil perolehan data angket, hasil penelitian menunjukan bahwa secara umum harga berpengaruh terhadap keputusan pembelian sim card AXIS yang dilakukan di lingkungan mahasiswa FKIP kampus 2 Universitas Swadaya Gunung Jati Cirebon. Dilihat dari hasil uji t, nilai $t_{\text {hitung variabel }}(\mathrm{X} 1)$ yaitu harga adalah lima koma tiga ratus enam puluh empat persen artinya nilai tersebut lebih besar dari nilai $t_{\text {tabel }}$ yaitu satu koma sembilan ratus delapan puluh enam persen. Maka dapat disimpulkan 
bahwa terdapat pengaruh yang signifikan antara variabel harga (X1) terhadap keputusan pembelian (Y).

Kedua, Berdasarkan hasil uji $\mathrm{F}$ yang bertujuan untuk menguji secara keseluruhan variabel secara bersama-sama, maka diketahui bahwa hasil uji f nilai $F_{\text {hitung variabel }}$ (X1) harga dan (X2) promosi secara bersama-sama adalah enam puluh sembilan koma sembilan ratus sembilan puluh satu persen yang artinya nilai tersebut lebih besar dari nilai $\mathrm{F}_{\text {tabel }}$ yaitu tiga koma delapan puluh tujuh persen. Dapat disimpulkan variabel harga dan promosi secara simultan berpengaruh terhadap keputusan pembelian sim card AXIS.

\section{BIBLIOGRAFI}

Arikunto, Suharsimi. (2014). Prosedur Penelitian: Suatu Pendekatan Praktik. Jakarta: Rineka cipta.

Assauri, Sofjan. (2015). Manajemen Pemasaran. Jakarta: PT. Rajagrafindo Persada.

Imam, Ghozali. (2011). Aplikasi analisis multivariate dengan program IBM SPSS 19. Semarang: Badan Penerbit Universitas Diponegoro.

Mahardika, Wahid Muslimin. (2015). Pengaruh tarif dan promosi terhadap keputusan membeli kartu prabayar produk Indosat IM3 oleh Mahasiswa UIN Walisongo. Semarang: Diss. UIN Walisongo.

Nugroho, Ari. (2017). Strategi Marketing Mix, Loyalitas Konsumen, Dan Efektifitas Kerja Terhadap Keputusan Pembelian La Lights. Syntax Literate; Jurnal Ilmiah Indonesia, 2(7), 26-39.

Riduwan. (2015). Belajar Mudah Penelitian. Bandung: Alfabeta.

Setiawati, Bekti. (2006). Pengaruh Kualitas Produk dan Promosi Terhadap Keputusan Pembelian Kerupuk Rambak "DWIJOYO” di Desa Penanggulan Kec. Pegandon Kab. Kendal. Universitas Negeri Semarang.

Sudaryono. (2018). Metodologi Penelitian. Depok: Rajawali Press.

Sugiyono. (2017). Metode Penelitian Kuantitaif, Kualitatif, Dan R\&D. Bandung: ALFABETA, cv.

1

Sugiyono. (2018). Metode penelitian pendidikan pendekatan kuantitatif, kualitatif, dan $R \& D$.

Sujarweni, V. Wiratna. (2015). Metodologi Penelitian Bisnis \& Ekonomi. Yogyakarta: 
Nasir Asman dan Nina Apriliani

Pustaka baru press.

Sumarwan, Ujang. (2011). Perilaku konsumen: Teori dan penerapannya dalam pemasaran. Bogor: Ghalia Indonesia.

Tukiran, Effendi dan. (2012). Metode Penelitian Survei. Jakarta: LP3ES.

Umar, Husein. (2014). Metode Penelitian Untuk Skripsi dan Thesis Bisnis Edisi Kedua. Jakarta: PT Raja Grafindo Persada.

Wijayanti, Titik. (2017). Marketing plan dalam bisnis. Penerbit Elex Media Komputindo Kelompok Gramedia. Jakarta.

Yamit, Zulian. (2010). Manajemen Kualitas Produk dan Jasa, Ekonisia. Yogyakarta. 